\title{
PERBEDAAN KEMAMPUAN KOMUNIKASI MATEMATIS SISWA PADA PEMBELAJARAN KOOPERATIF TIPE THINK PAIR SHARE DAN PEMBELAJARAN KOOPERATIF TIPE TWO STAY TWO STRAY DI KELAS VIII SMP N 27 MEDAN
}

\author{
Rizka Aulia ${ }^{1}$, Waminton Rajagukguk ${ }^{2}$ \\ ${ }^{1}$ Fakultas Matematika dan Ilmu Pengetahuan Alam, Universitas Negeri Medan (UNIMED) \\ e-mail: auliarizka85@gmail.com \\ ${ }^{2}$ Fakultas Matematika dan Ilmu Pengetahuan Alam, Universitas Negeri Medan (UNIMED) \\ e-mail: waminton@gmail.com
}

\begin{abstract}
Abstrak
Penelitian ini bertujuan untuk melihat bahwa kemampuan komunikasi matematis siswa pada pembelajaran kooperatif tipe TPS berbeda dengan pembelajaran kooperatif tipe TSTS di kelas VIII SMP Negeri 27 Medan. Jenis penelitian ini adalah kuasi-eksperimen. Populasi dalam penelitian ini adalah seluruh siswa kelas VIII semester genap yang terdiri dari 9 kelas dengan jumlah keseluruhan siswa 362 orang. Pengambilan sampel dilakukan dengan cara cluster sampling dengan mengambil 2 kelas dari 9 kelas secara acak, maka terpilih kelas VIII-7 sebagai kelas eksperimen 1 yang berjumlah 40 orang dan kelas VIII-8 sebagai kelas eksperimen 2 yang berjumlah 40 orang. Penelitian ini menggunakan instrumen dalam bentuk uraian yaitu posttest yang digunakan untuk mengetahui kemampuan komunikasi matematis siswa. Instrumen tes tersebut telah divalidasi oleh tiga orang validator kompeten yaitu dua validator merupakan dosen pendidikan matematika dan satu validator merupakan guru matematika dan telah dinyatakan valid. Dari hasil penelitian setelah diberikan perlakuan yang berbeda yaitu kelas eksperimen 1 dengan model pembelajaran kooperatif tipe TPS dan kelas eksperimen 2 dengan model pembelajaran kooperatif tipe TSTS diperoleh nilai rata-rata kelas eksperimen 1 sebesar 72,5000 dan nilai rata-rata kelas eksperimen 2 sebesar 63,9060. Hasil uji $t$ dua pihak dengan $d k=78$ dan $\alpha=0,05$, diperoleh $t_{\text {hitung }}=1,7489$ dan $t_{\text {tabel }}=1,667$ sehingga $t_{\text {hitung }}$ tidak berada dalam interval $-t_{\text {tabel }}<t_{\text {hitung }}<t_{\text {tabel }}$ maka Ha diterima, dengan demikian diperoleh kesimpulan bahwa kemampuan komunikasi matematis siswa pada pembelajaran kooperatif tipe Think Pair Share (TPS) berbeda dengan pembelajaran kooperatif tipe Two Stay Two Stray (TSTS) di kelas VIII SMP Negeri 27 Medan.
\end{abstract}

Kata kunci: Model pembelajaran kooperatif tipe Think Pair Share (TPS), Model pembelajaran kooperatif tipe Two Stay Two Stray (TSTS), kemampuan komunikasi matematis

\begin{abstract}
Abstrak
This researchaims to see that the mathematical communication skills of students incooperative learning types Think pair share (TPS) different cooperative learning with types Two Stay Two Stray (TSTS) in class VIII SMP Negeri Medan 27. This type of research is quasi-experiments. The population in this research is all students of SMP Negeri 27 Medan consist of 9 class with the number of overall students 362 people. Sampling is done by means of cluster sampling taking 2 classes from grade 9 at random, then elected to class VIII7 as a class experiment 1 of 40 people and class VIII-8 experiments as a class 2 that add up to 40 people. This research uses the instrument in the form of exposé i.e. posttest are used to figure out the mathematical communication skills of students. The test instrument has been validated by three competent two validator the validator is a Professor of mathematics
\end{abstract}

Rizka Aulia, Waminton Rajagukguk. Perbedaan Kemampuan Komunikasi Matematis Siswa pada Pembelajaran Kooperatif Tipe Think Pair Share dan Pembelajaran Kooperatif Tipe Two Stay Two Stray di Kelas VIII SMP N 27 Medan. Jurnal Inspiratif, Vol. 3, No. 3 Desember 2017. 
education and a validator is a mathematics teacher and has been declared invalid. From the results of the study after being given different treatment experimental class 1 with cooperative learning model type TPS and experimental class 2 with cooperative learning model type TSTS obtained average value of experimental class 1 for 72.5000 and the average value of experimental class 2 of 63.9060. T test result two parties with $d k=78$ and $\alpha=0,05$, retrieved $t_{\text {hitung }}=1.7489$ and $t_{\text {tabel }}=1.667$ so that $t_{\text {hitung }}$ are not in interval $-t_{\text {tabel }}<t_{\text {hitung }}<t_{\text {tabel }}$ and then Ha received, thus obtained the conclusion that mathematical communication skills of students in cooperative learning types Think Pair Share (TPS) cooperative learning with different types of Two Stay Two Stray (TSTS) in class VIII SMP Negeri Medan 27.

Keywords: Cooperative learning model types Think Pair Share (TPS), cooperative learning Model types of Two Stay Two Stray (TSTS), communication skills matematis

\section{PENDAHULUAN}

Pendidikan merupakan hal yang sangat penting bagi manusia, karena pendidikan merupakan investasi sumber daya manusia dalam jangka panjang. Pendidikan juga merupakan wadah yang dapat dipandang dan berfungsi sebagai alat untuk membangun sumber daya manusia yang mampu bersaing di era global (Santillán, dkk, 2016:361).

Matematika merupakan salah satu mata pelajaran yang menduduki peranan penting dalam pendidikan. Matematika merupakan ilmu yang mendasari perkembangan teknologi, karena mempunyai peran penting dalam berbagai disiplin ilmu dan memajukan daya pikir manusia. Matematika selalu berhubungan dengan mata pelajaran yang lain. Matematika diajarkan di segala jenjang pendidikan dasar hingga pendidikan menengah. Matematika juga merupakan mata pelajaran yang paling penting dalam kurikulum di seluruh dunia karena matematika memiliki hubungan langsung dengan mata pelajaran lain (Sa'ad, dkk, 2014:32). Selain itu Byod, dkk (2014:207208) menyatakan bahwa :Memahami matematika diakui sebagai hal penting dalam kehidupan sehari-hari dan matematika merupakan bagian dari pekerjaan professional seperti tehnik, kedokteran, ilmu pengetahuan dan pendidikan. Sehingga guru diharapkan kompeten akan keterampilan matematika mereka, memiliki pemahaman yang mendalam dan mampu mengajar secara efektif sehingga siswa berhasil dalam pembelajaran matematika.

Cockroft (dalam Abdurrahman, 2012:204) menyatakan ada 6 (enam) alasan mengapa meningkatkan kualitas pendidikan matematika penting diakukan, yaitu:

1) selalu digunakan dalam segala segi kehidupan; 2) semua bidang studi memerlukan keterampilan matematika yang sesuai; 3) merupakan sarana komunikasi yang kuat; 4) dapat digunakan untuk menyajikan informasi dalam berbagai cara; 5) meningkatkan kemampuan berfikir logis, ketelitian dan kesadaran keruangan; dan 6) memberikan kepuasan terhadap usaha memecahkan masalah yang menantang.

Peran matematika dalam tujuan pendidikan adalah mempersiapkan siswa agar sanggup menghadapi perubahan keadaan yang selalu berkembang melalui latihan berpikir kritis, rasional dan cermat serta dapat menggunakan pola pikir matematika baik dalam mempelajari berbagai ilmu pengetahuan maupun dalam kehidupan sehari-hari.

Salah satu kemampuan matematis yang harus dimiliki siswa adalah kemampuan komunikasi. Komunikasi berperan penting untuk mengetahui dan mengerjakan matematika, dengan kemampuan berkomunikasi siswa dapat memecahkan masalah-masalah dalam kehidupan sehari-hari baik di dalam maupun di luar sekolah. Salah satu bentuk komunikasi matematis adalah kegiatan memahami matematika. Memahami

Rizka Aulia, Waminton Rajagukguk. Perbedaan Kemampuan Komunikasi Matematis Siswa pada Pembelajaran Kooperatif Tipe Think Pair Share dan Pembelajaran Kooperatif Tipe Two Stay Two Stray di Kelas VIII SMP N 27 Medan. Jurnal Inspiratif, Vol. 3, No. 3 Desember 2017. 
matematika memiliki peran sentral dalam pembelajaran matematika. Sebab, kegiatan memahami mendorong peserta didik belajar bermakna secara aktif.

Menurut Asikin (dalam Muhammad Darkasyi, 2014) komunikasi matematis dapat diartikan sebagai suatu peristiwa saling hubungan/dialog yang terjadi dalam suatu lingkungan kelas, dimana terjadi pengalihan pesan. Pesan yang dialihkan berisi tentang materi matematika yang dipelajari di kelas, komunikasi di lingkungan kelas adalah guru dan siswa. Sedangkan cara pengalihan pesan dapat secara tertulis maupun lisan yang disampaikan guru kepada peserta didik untuk saling komunikasi, sehingga komunikasi dapat berjalan dengan lancar dan sebaliknya jika komunikasi antara siswa dengan guru tidak berjalan dengan baik maka akan rendahnya kemampuan komunikasi matematik. Surya (2012) menyatakan bahwa kenyataan di sekolah hasil belajar matematika rendah karena sebagian besar siswa kurang antusias, takut dan ketidakmampuan guru menciptakan situasi dan kondisi yang membawa siswa tertarik pada matematika. Hal ini mengindikasikan ada sesuatu yang salah dan belum optimal dalam pembelajaran matematika. Pada dasarnya siswa sangat membutuhkan pembelajaran yang menarik, menantang, inovatif, dan menyenangkan.

Kemampuan komunikasi matematis mencangkup komunikasi secara tertulis dan lisan. Lacoe (dalam Mahmudi, 2009) menyatakan bahwa,

"Komunikasi tertulis dapat berupa penggunaan kata-kata, gambar, tabel dan sebagainya yang menggambarkan proses berfikir siswa. Komunikasi tertulis juga dapat berupa uraian pemecahan masalah atau pembuktian matematika yang menggambarkan kemampuan siswa dalam mengorganisasikan berbagai konsep untuk menyelesaikan masalah. Sedangkkan komunikasi lisan dapat berupa pengungkapan dan penjelasan verbal suatu gagasan matematika".
Berdasarkan informasi yang didapat dari salah satu guru matematika di SMP Negeri 27 Medan yakni ibu Rospita Gultom yang menyatakan bahwa ada beberapa kesulitan yang dihadapi siswa dalam memecahkan soal matematika yang dalam penyelesaiannya membutuhkan kreatifitas dan imajinasi. Selain itu ada juga siswa yang tidak bisa menentukan rencana penyelesaian dari soal tersebut. Hal ini terlihat dari hasil belajar siswa yang kurang maksimal saat diberikan soal terutama pada soal-soal penerapan.

Kesulitan yang diperoleh siswa adalah pada saat memahami, menggambar diagram, membaca grafik dengan benar, pemahaman konsep matematika formal, dan penyelesaian masalah matematika. Penyajian masalah yang tepat adalah hal mendasar dalam memahami masalah tersebut dan membuat rencana untuk menyelesaikannya (Surya, dkk., 2013).

Dari hasil survei penelitian berupa pemberian tes diagnostik kepada siswa SMP Negeri 27 Medan di kelas VIII. Dari 40 siswa yang mengikuti tes terdapat 3 orang $(7,5 \%)$ siswa yang memiliki kemampuan komunikasi kategori tinggi, 25 orang $(62,5 \%)$ siswa yang memiliki kemampuan komunikasi kategori rendah, dan 12 orang (30\%) siswa yang memiliki kemampuan komunikasi sangat rendah karena mereka tidak mampu menjelaskan, menggambarkan, serta merepresentasikan soal yang diberikan.

Ibrahim (dalam Ratih Kusumaningrum, dkk:2015) menyatakan bahwa dalam kegiatan pembelajaran di kelas, kegiatan belajar siswa dapat ditingkatkan melaluai proses berfikir yang dibarengi dengan interaksi sosial. Pada saat yang sama manfaat dari interaksi bagi masing-masing siswa adalah adanya perluasan yang diakibatkan oleh ide-ide yang dibawa para siswa kedalam diskusi. Salah satu model pembelajaran yang memberikan kesempatan kepada siswa untuk berinteraksi sosial adalah model pembelajaran gotong royong atau cooperatif learning.

Ada banyak tipe dari model pembelajaran kooperatif diantaranya model

Rizka Aulia, Waminton Rajagukguk. Perbedaan Kemampuan Komunikasi Matematis Siswa pada Pembelajaran Kooperatif Tipe Think Pair Share dan Pembelajaran Kooperatif Tipe Two Stay Two Stray di Kelas VIII SMP N 27 Medan. Jurnal Inspiratif, Vol. 3, No. 3 Desember 2017. 
pembelajaran kooperatif tipe Think Paire Share (TPS). Model pembelajaran kooperatif tipe Think-Pair-Share (TPS) merupakan salah satu tipe pembelajaran kooperatif yang dikembangkan oleh Frank Lyman dan koleganya dari Universitas Maryland pada tahun 1985. Think-PairShare (TPS) memberikan waktu pada para siswa untuk berfikir dan merespon serta saling bantu satu sama lain. Think-PairShare (TPS) juga memberi kesempatan kepada siswa untuk bekerja sendiri serta bekerja sama dengan orang lain. Isjoni (2011:78) mengatakan bahwa,

"Teknik ini (model pembelajaran kooperatif tipe TPS memberikan kesempatan kepada siswa untuk bekerja sendiri serta bekerja sama dengan orang lain. Keunggulan teknik ini adalah optimalisasi partisipasi siswa, yaitu memberikan kesempatan delapan kali lebih banyakkepada setiap siswa untuk dikenali dan menunjukkan partisipasi mereka kepada orang lain".

Dari uraian diatas model pembelajaran kooperatif tipe Think-PairShare (TPS) melibatkan siswa untuk berinteraksi dan berkomunikasi secara aktif dengan temannya. Model ini menuntut para siswa untuk memiliki kemampuan yang baik dalam berkomunikasi maupun dalam keterampilan proses kelompok.

Selain model pembelajaran kooperatif tipe Think-Pair-Share (TPS), model pembelajaran kooperatif lainnya adalah Two Stay Two Stray (TSTS). Pembelajaran kooperatif tipe Two Stay Two Stray (TSTS) mudah dipecah menjadi berpasangan, lebih banyak tugas yang biasa dilakukan, guru mudah memonitor, dapat diterapkan pada semua kelas/tingkatan, kecenderungan belajar siswa menjadi lebih bermakna, lebih berorientasi pada keaktifan, diharapkan siswa akan berani mengungkapkan pendapatnya, menambah kekompakan dan rasa percaya diri siswa, dan membantu meningkatkan minat dan prestasi belajar.

Berdasarkan hasil penelitian Husna, M. Ikhsan, Siti Fatimah (2013) menyimpulkan bahwa Peningkatan kemampuan komunikasi matematis siswa yang memperoleh model pembelajaran kooperatif tipe Think-Pair-Share lebih baik dari pada siswa yang memperoleh pembelajaran konvensional, ditinjau dari keseluruhan siswa dan peringkat siswa tinggi dan sedang. Kemudian penelitian yang dilakukan oleh Dian Mayasari (2014) menyimpulkan bahwa model pembelajaran kooperatif tipe Two Stay Two Stray (TSTS) dapat meningkatkan kemampuan komunikasi matematis siswa.

Dari penjabaran diatas dapat disimpulkan bahwa model pembelajaran kooperatif tipe Think-Pair-Share (TPS) dan Two Stay Two Stray (TSTS) dapat meningkatkan kemampuan komunikasi matematis siswa. Karena keduanya mampu meningkatkan kemampuan komunikasi matematis siswa, maka penulis tertarik ingin melihat perbedaan kemampuan komunikasi matematis antara model pembelajaran kooperatif tipe TPS (ThinkPair-Share) dan model pembelajaran kooperatif tipe Two Stay Two Stray (TSTS).

\section{METODE PENELITIAN}

Penelitian ini dilaksanakan di SMP Negeri 27 Medan. Dengan alasan bahwa di sekolah ini belum pernah dilakukan penelitian yang sejenis. Waktu penelitian dilaksanakan pada semester II tahun ajaran 2016/2017. Populassi dalam penelitian ini adalah seluruh siswa kelas VIII SMP Negeri 27 Medan Tahun Ajaran 2016/2017 yang terdiri dari 9 (sembilan) kelas.

Pengambilan sampel dalam penelitian ini dilakukan secara simple random sampling. Siswa kelas VIII dalam penelitian ini bersifat homogen yaitu kelas VIII-7 yang diajarkan dengan menggunakan model pembelajaran kooperatif tipe Think Pair Share (TPS) yang disebut sebagai kelas eksperimen I dan kelas VIII-8 yang diajarkan dengan menggunakan model pembelajaran kooperatif tipe Two Stay Two Stray (TSTS) yang disebut sebagai kelas eksperimen II, dengan masing-masing kelas terdiri atas 40 siswa.

Rizka Aulia, Waminton Rajagukguk. Perbedaan Kemampuan Komunikasi Matematis Siswa pada Pembelajaran Kooperatif Tipe Think Pair Share dan Pembelajaran Kooperatif Tipe Two Stay Two Stray di Kelas VIII SMP N 27 Medan. Jurnal Inspiratif, Vol. 3, No. 3 Desember 2017. 
Jenis penelitian ini adalah kuasieksperimen karena kondisi siswa tidak dapat dikontrol sepenuhnya seperti: persiapan siswa sebelum belajar disekolah, les tambahan di luar jam sekolah, hubungan siswa dengan orang tua, hubungan siswa dengan lingkungannya, dan lain sebagainya.

Variabel adalah objek penelitian atau apa yang menjadi titik perhatian suatu penelitian. Sanjaya (2013:95) menyatakan bahwa, "variabel adalah segala faktor, kondisi, situasi, perlakuan (treatment) dan semua tindakan yang bisa dipakai untuk mempengaruhi hasil eksperimen." Dalam penelitian eksperimen untuk melihat pengaruh, variabel dikelompokkan menjadi variabel bebas (independent variable) dan variabel terikat (dependent variable)

Berikut ini adalah variabel-variabel bebas yang terdapat dalam penelitian:

a. Varibel Perlakuan, terdiri dari:

Kelas Eksperimen I: Think-Pair-Shar (TPS) Kelas Eksperimen II: Two Stay Two Stray (TSTS)

b. Variabel Kontrol, yaitu:

1. Guru : Peneliti sebagai guru di kedua kelas eksperimen

2. Topik : Kedua kelas mendapatkan topik yang sama yaitu Kubus dan Balok.

3. Buku: Buku yang digunakan oleh kedua kelas harus sama

4. Waktu: Alokasi waktu yang digunakan dalam proses pembelajaran di kedua kelas adalah sama

c. Variabel Tidak Dapat Dikontrol

Variabel bebas yang tidak dikontrol adalah variabel bebas yang mempengaruhi perbedaan kemampuan Komunikasi matematis siswa tetapi tidak dianalisis. Dalam penelitian ini diasumsikan variabel tersebut sama. Variabel itu adalah tingkat kecerdasan siswa, kemampuan awal, fasilitas belajar di rumah, kondisi kesehatan siswa, latar belakang pendidikan orang tua dan lain-lain.

Sugiono (2008:39) menyatakan bahwa, "Variabel terikat adalah variabel yang dipengaruhi atau yang menjadi akibat, karena adanya variabel bebas." Variabel terikat dalam penelitian ini adalah kemampuan komunikasi matematis. Hubungan antara variabel bebas dengan variabel terikat ditunjukkan pada gambar berikut:

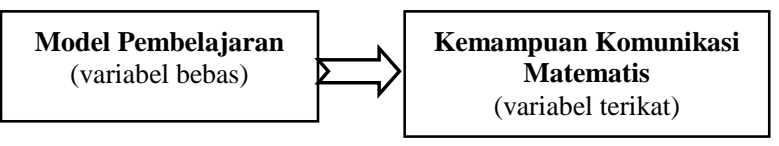

Gambar 1. Hubungan antara variabel bebas dengan variabel terikat

\section{Desain dan Mekanisme Penelitian}

\section{Desain Penelitian}

Penelitian ini menggunakan dua kelas sampel yang akan dibedakan yaitu Kelas Eksperimen I dan Kelas Eksperimen II. Kelas Eksperimen I diberikan perlakuan dengan menerapkan model pembelajaran kooperatif tipe Think Pair Share, sedangkan Kelas Eksperimen II diberikan perlakuan dengan menerapkan model pembelajaran kooperatif tipe Two Stay Two Stray. Dalam penelitian ini kemampuan awal kelas eksperimen I dan kelas eksperimen II diasumsikan sama maka diberikan tes sebanyak satu kali yaitu sesudah perlakuan. Tes yang diberikan sesudah perlakuan disebut posttest. Rancangan penelitian dapat digambarkan sebagai berikut :

\section{Tabel 1. Posttest Only Control Design}

\begin{tabular}{|c|c|c|}
\hline Kelas & Perlakuan & $\begin{array}{c}\text { Pengukuran } \\
\text { Posttest }\end{array}$ \\
\hline $\begin{array}{c}\text { Eksperimen } \\
\text { I }\end{array}$ & $\mathrm{P}_{\mathrm{X}_{1}}$ & $\mathrm{~T}_{\mathrm{X}_{1}}$ \\
\hline $\begin{array}{c}\text { Eksperimen } \\
\text { II }\end{array}$ & $\mathrm{P}_{\mathrm{X}_{2}}$ & $\mathrm{~T}_{\mathrm{X}_{2}}$ \\
\hline
\end{tabular}

Keterangan:

$\mathrm{P}_{\mathrm{X}_{1}}$ : Perlakuan yang akan diberikan pada

kelas eksperimen I dengan model pembelajaran Think Pair Share

$\mathrm{P}_{\mathrm{X}_{2}}$ : Perlakuan yang akan diberikan pada kelas eksperimen II dengan model pembelajaran Two Stay Two Stray

$\mathrm{T}_{\mathrm{x}_{1}}$ : Tes akhir (posttest) yang diberikan pada kelas eksperimen I

Rizka Aulia, Waminton Rajagukguk. Perbedaan Kemampuan Komunikasi Matematis Siswa pada Pembelajaran Kooperatif Tipe Think Pair Share dan Pembelajaran Kooperatif Tipe Two Stay Two Stray di Kelas VIII SMP N 27 Medan. Jurnal Inspiratif, Vol. 3, No. 3 Desember 2017. 
$\mathrm{T}_{\mathrm{x}_{2}}$ : Tes akhir (posttest) yang diberikan pada kelas eksperimen II

\section{Mekanisme Penelitian}

Mekanisme penelitian terdiri dari beberapa tahapan. Tahapan-tahapan tersebut adalah sebagai berikut:

a. Tahap persiapan

1. Menentukan tempat dan jadwal pelaksanaan

2. Menentukan populasi dan sampel

3. Menyusun rencana pembelajaran dengan menggunakan model pembelajaran kooperatif tipe Think Pair Share pada materi kubus dan balok dan rencana pembelajaran kooperatif tipe Two Stay Two Stray pada materi kubus dan balok.

4. Rencana pembelajaran setiap kelas dibuat dalam 2 kali pertemuan, dimana satu kali pertemuan adalah 90 menit.

5. Menetapkan kelas eksperimen I dan kelas eksperimen II.

6. Menyiapkan alat pengumpul data berupa posttest.

\section{b. Tahap Pelaksanaan}

1. Melakukan validasi instrumen penelitian.

2. Mengadakan pembelajaran pada dua kelas dengan materi pelajaran dan waktu yang sama yaitu pada semester II tahun ajaran 2016/2017, hanya model pembelajaran yang berbeda. Untuk kelas eksperimen I diberikan perlakuan model pembelajaran kooperatif tipe Think Pair Share, sedangkan kelas eksperimen II diberikan perlakuan model pembelajaran kooperatif tipe Two Stay Two Stray.

3 Memberikan posttest kepada kedua kelas. Waktu dan lama pelaksanaan postes kedua kelas adalah sama.

c. Tahap Akhir

1. Melakukan pengolahan data posttest untuk menguji hipotesis.

2. Melakukan uji hipotesis dengan menggunakan statistik-t untuk menentukan apakah kemampuan komunikasi matematis pada kelas eksperimen I berbeda dengan

kemampuan komunikasi matematis siswa pada kelas eksperimen II secara signifikan, yaitu apakah perbedaan tersebut cukup besar untuk menolak hipotesis nol.

3. Menyimpulkan hasil penelitian.

\section{Instrumen Penelitian}

Intrumen data penelitian yang digunakan peneliti dalam penelitian ini adalah tes tertulis. Tes yang digunakan merupakan tes kemampuan komunikasi matematis yang diuraikan dalam penyelesaiannya. Posttest (tes akhir) digunakan untuk mengetahui kemampuan komunikasi matematis siswa (pengujian hipotesis).

Setiap pertanyaan memuat semua indikator untuk mengetahui kemampuan komunikasi matematis siswa. Tes yang digunakan disusun sesuai kurikulum dan tujuan pengajaran yang ditentukan. Instrumen dalam penelitian ini adalah tes yang masing-masing berbentuk soal uraian dan berjumlah 4 soal.

\section{Validitas Isi Tes}

Validitas isi suatu tes mempermasalahkan seberapa jauh suatu tes mengukur tingkat penguasaan terhadap idi suatu materi tertentu yang seharusnya dikuasai sesuai dengan tujuan pengajaran. Menurut Gregory, validitas isi menunjukkan tingkat sejauh mana pertanyaan, tugas atau butis dalam suatu tes mampu mewakili secara keseluruhan perilaku sampel yang dikenai tes tersebut. Lebih lanjut menurut Wiersma dan Jurs, validita $s$ isi sebenarnya mendasar pada analisis logika, jadi tidak merupakan suatu koefisien validitas (Asmin dan Abil, 2012:238). Oleh karena itu, untuk memperbaiki validitas isi tes dalam penelitian ini didasarkan pada pendapat para ahli dalam bidang bersangkutan. Difokuskan pada format soal, pemakaian bahasa soal, pemakaian bahasa soal, kesesuaian materi dengan soal yang diujikan serta kesesuaian soal dengan indicator kemampuan pemecahan masalah.

Ahli yang dimaksud dalam hal ini adalah para validator yang berkompeten

Rizka Aulia, Waminton Rajagukguk. Perbedaan Kemampuan Komunikasi Matematis Siswa pada Pembelajaran Kooperatif Tipe Think Pair Share dan Pembelajaran Kooperatif Tipe Two Stay Two Stray di Kelas VIII SMP N 27 Medan. Jurnal Inspiratif, Vol. 3, No. 3 Desember 2017. 
untuk menilai dan memberikan masukan dan kritikan guna menyempurnakan postes. Validator tersebut yaitu 2 orang dosen Universitas Negeri Medan dan 1 orang guru matematika SMP Negeri 27 Medan.

\section{Teknik Analisis Data}

Terdapat dua jenis analisis data pada penelitian ini. Analisis statistik deskriptif digunakan untuk mendeskripsikan data antara lain : nilai minimum, nilai maksimum, jumlah, rata-rata (mean), standar deviasi dan varians. Dan analisis statistik inferensial digunakan dalam penelitian persyaratan analisis data yakni persyaratan normalitas dan homogenitas.

\section{Analisis Statistik Deskriptif}

Deskriptif digunakan untuk mendeskripsikan data antara lain : nilai minimum, nilai maksimum, jumlah, ratarata (mean), standar deviasi dan varians. Dari hasil posttest kelas eksperimen I dan kelas eksperimen II yang dilakukan kedua kelas bertujuan untuk mengetahui sejauhmana kemampuan komunikasi matematis siswa.

\section{$>$ Menghitung Mean}

Untuk menghitung nilai rata-rata digunakan rumus (Sudjana, 2005:67), yaitu:

$$
\bar{X}=\frac{\sum_{i=1}^{n} x_{i}}{n}
$$

Keterangan:

$\bar{X}$ : rata-rata

$x_{i}:$ nilai/skor ke-i

$\mathrm{n}$ : banyaknya data

\section{Menghitung Varians}

Untuk menghitung varians $s^{2}$ digunakan rumus (Sudjana, 2005:94), yaitu:

$S^{2}=\frac{n \sum_{i=1}^{n} x_{i}^{2}-\left(\sum_{i=1}^{n} x_{i}\right)^{2}}{n(n-1)}$

Dengan:

$S^{2}$ : Varians

$\mathrm{n}$ : banyaknya data

$x_{i}$ : nilai data kelas ke $-\mathrm{i}$

\section{Menghitung Simpangan Baku}

Untuk menghitung simpangan baku (s) digunakan rumus (Sudjana, 2005:94), yaitu:
$S=\sqrt{\frac{n \sum_{i=1}^{n} x_{i}^{2}-\left(\sum_{i=1}^{n} x_{i}\right)^{2}}{n(n-1)}}$

Dengan,

$S$ : Simpangan baku

$x_{i}$ : nilai data kelas ke-i

$\mathrm{n}$ : banyaknya data

\section{Analisis Statistik Inferensial}

Setelah data posttest diperoleh dilakukan analisis dan pengolahan data. Pengolahan data dilakukan dengan bantuan program Microsof Excel. Dari hasil pengolahan data yang diperoleh, dapat ditentukan kemampuan komunikasi matematis siswa dari model pembelajaran Think Pair Share (TPS) dan siswa yang diajar dengan model pembelajaran Two Stay Two Stray (TSTS). Teknik inferensial yang digunakan dalam penelitian persyaratan analisis data yakni persyaratan normalitas dan homogenitas.

\section{$>\quad$ Uji Normalitas}

Untuk menguji apakah sampel berasal dari populasi yang berdistribusi normal atau tidak digunakan uji normalitas Liliefors. Metode liliefors menggunakan data dasar yang belum diolah dalam tabel distribusi frekuensi. Data ditransformasikan dalam nilai $\mathrm{Z}$ untuk dapat dihitung luasan kurva normal sebagai probabilitas kumulatif normal. Langkah-langkahnya adalah sebagai berikut:

1. Data hasil belajar $X_{1}, X_{2}, \ldots, X_{n}$ diubah ke dalam bentuk $Z_{1}, Z_{2}, \ldots, Z_{n}$ dengan menggunakan rumus:

Keterangan :

$$
Z_{i}=\frac{X_{i}-\bar{X}}{S}
$$

$X_{i}=$ Data ke-i

$\bar{X}=$ Rata-rata sampel

$\mathrm{S}=$ Simpangan baku

2. Menghitung peluang $F\left(Z_{i}\right)=P(Z \leq$ $Z_{i}$ ), dengan menggunakan daftar distribusi normal baku.

3. Menghitung proporsi $S\left(Z_{i}\right)$ dengan rumus:

$$
S\left(Z_{i}\right)=\frac{\text { banyaknya } \mathrm{Z}_{1}, \mathrm{Z}_{2}, \ldots, \mathrm{Z}_{\mathrm{n}} \leq \mathrm{Z}_{\mathrm{i}}}{\mathrm{n}}
$$

4. Menghitung selisih $F\left(Z_{i}\right)-S\left(Z_{i}\right)$ kemudian ditentukan harga mutlaknya.

5. Menentukan harga terbesar dari selisih harga mutlak $F\left(Z_{i}\right)-S\left(Z_{i}\right)$ sebagai $L_{0}$. Untuk menerima dan menolak distribusi

Rizka Aulia, Waminton Rajagukguk. Perbedaan Kemampuan Komunikasi Matematis Siswa pada Pembelajaran Kooperatif Tipe Think Pair Share dan Pembelajaran Kooperatif Tipe Two Stay Two Stray di Kelas VIII SMP N 27 Medan. Jurnal Inspiratif, Vol. 3, No. 3 Desember 2017. 
normal data penelitian dapatlah dibandingkan nilai $L_{0}$ dengan nilai kritis $\mathrm{L}$ uji liliefors dengan taraf signifikan $\alpha=$ 0,05 .

Dengan daerah kriteria :

Jika $L_{0}<L_{\text {tabel }}$ maka populasi

berdistribusi normal

Jika $L_{0}>L_{\text {tabel }}$ maka populasi tidak berdistribusi normal

(Sudjana, $2005:$ 466)

\section{Uji Homogenitas}

Uji Homogenitas digunakan untuk menguji apakah varians kedua populasi tersebut homogen. Adapun uji yang digunakan uji homogenitas dengan hipotesis:

$H_{0}: \sigma_{1}{ }^{2}=\sigma_{2}{ }^{2}$ (kedua populasi mempunyai varians yang sama)

$H_{a}:{\sigma_{1}}^{2} \neq{\sigma_{2}}^{2}$ (kedua populasi tidak mempunyai varians yang sama)

Uji homogenitas ini dilakukan dengan menggunakan uji $\mathrm{F}$ dengan rumus:

$F=\frac{\text { varians terbesar }}{\text { varians terkecil }}=\frac{s_{1}^{2}}{s_{2}^{2}}$

Dimana : $S_{1}^{2}=$ varians terbesar

$S_{2}^{2}=$ varians terkecil

Kriteria pengujian adalah sebagai berikut :

Jika $F_{\text {hitung }}<F_{\text {tabel }}$ maka Ho diterima

Jika $\quad F_{\text {hitung }} \geq F_{\text {tabel }}$ maka Ho ditolak

Dimana $F_{\frac{1}{2} \alpha\left(v_{1}, v_{2}\right)}$ didapat dari daftar distribusi $\mathrm{F}$ dengan peluang $\frac{1}{2} \alpha$, sedangkan derajat kebebasan $v_{1}$ dan $v_{2}$ masing-masing sesuai dengan $\mathrm{dk}$ pembilang $=\left(n_{1}-1\right) \mathrm{dan} \mathrm{dk}$ penyebut $=\left(n_{2}-1\right)$ pembilang dan taraf nyata $\alpha=0,05$.

\section{Uji Hipotesis}

(Sudjana, $2005: 250$ )

Hipotesis yang akan di uji dirumuskan sebagai berikut :

1) Hipotesis Penelitian

$\mathrm{H}_{\mathrm{o}}$ : Komunikasi matematis siswa yang diajarkan dengan model pembelajaran Think Pair Share tidak berdeda dengan komunikasi matematis siswa yang diajarkan dengan model pembelajaran Two Stay Two Stray pada pokok pembahasan bangun ruang kubus dan balok di kelas VIII SMP Negeri 27 Medan tahun ajaran 2016/2017.
$\mathrm{H}_{\mathrm{a}} \quad$ : Komunikasi matematis siswa yang diajarkan dengan model pembelajaran Think Pair Share berbeda dengan komunikasi matematis siswa yang diajarkan dengan model pembelajaran Two Stay Two Stray pada pokok pembahasan bangun ruang kubus dan balok di kelas VIII SMP Negeri 27 Medan tahun ajaran 2016/2017. Hipotesis Statistik

$\mathrm{H}_{\mathrm{o}}: \mu_{1}=\mu_{2}$

$\mathrm{H}_{\mathrm{a}}: \mu_{1} \neq \mu_{2}$

Dimana:

$\mu_{1}$ : Komunikasi matematis siswa yang diajarkan dengan model pembelajaran Think Pair Share (TPS)

$\mu_{2}$ : Komunikasi matematis siswa yang diajarkan dengan model pembelajaran Two Stay Two Stray (TSTS)

Uji hipotesis statistik yang digunakan

$$
\begin{gathered}
\text { adalah } t=\frac{\bar{X}_{1}-\bar{X}_{2}}{S \sqrt{\frac{1}{n_{1}}+\frac{1}{n_{2}}}} \quad \\
S^{2}=\frac{\left(n_{1}-1\right) S_{1}^{2}+\left(n_{2}-1\right) S_{2}^{2}}{n_{1}+n_{2}-2}
\end{gathered}
$$

(Sudjana, $2005: 239$ )

$\mathrm{t}=$ Luas daerah yang dicapai

$\mathrm{n}_{1}=$ Banyak siswa pada sampel kelas eksperimen I

$\mathrm{n}_{2}=$ Banyak siswa pada sampel kelas eksperimen II

$S_{1}^{2}=$ Varians kelas eksperimen I

$S_{2}^{2}=$ Varians kelas eksperimen II

$S^{2}=$ Varians gabungan dari $S_{1}^{2}$ dan $S_{2}^{2}$

$\mathrm{S}=$ Simpangan baku

$\overline{X_{1}}=$ Rata-rata skor test komunikasi akhir siswa kelas eksperimen I

$\overline{X_{2}}=$ Rata-rata skor test komunikasi akhir siswa kelas eksperimen II

Kriteria Pengujian

Terima $\mathrm{H}_{\mathrm{o}}$ jika $-t_{\left(1-\frac{1}{2} \alpha\right)}<t<t_{\left(1-\frac{1}{2} \alpha\right)}$ dimana $t_{\left(1-\frac{1}{2} \alpha\right)}$ didapat dari daftar $\mathrm{t}$ dengan $\mathrm{dk}=\left(n_{1}+n_{2}-2\right)$ dan peluang $\left(1-\frac{1}{2} \alpha\right)$

Rizka Aulia, Waminton Rajagukguk. Perbedaan Kemampuan Komunikasi Matematis Siswa pada Pembelajaran Kooperatif Tipe Think Pair Share dan Pembelajaran Kooperatif Tipe Two Stay Two Stray di Kelas VIII SMP N 27 Medan. Jurnal Inspiratif, Vol. 3, No. 3 Desember 2017. 
dan taraf nyata $\alpha=0,05$. Sementara untuk harga-harga $t$ lainnya $\mathrm{H}_{0}$ ditolak.

\section{HASIL DAN PEMBAHASAN PENELITIAN}

\section{Deskripsi Hasil Penelitian}

Dalam penelitian ini kelas yang diambil secara acak dikelompokkan menjadi dua kelas yaitu kelas eksperimen I dan kelas eksperimen II. Kedua kelas yang telah diambil tersebut diacak untuk menentukan kelas eksperimen I dan kelas eksperimen II. Kelas eksperimen I yang belajar dengan model pembelajaran kooperatif tipe TPS berjumlah 40 orang siswa sedangkan kelas eksperimen II yang belajar dengan model pembelajaran kooperatif tipe TSTS berjumlah 40 orang siswa, sehingga sampel penelitian ini berjumlah 80 orang siswa.

Kedua kelas diberi materi pembelajaran yang sama dengan metode yang berbeda. Setelah proses pembelajaran selesai kedua kelas diberi posttest. Hasil posttest diperiksa sebagai data hasil belajar siswa. Data yang terkumpul berupa data skor yang diperoleh dari hasil tes yaitu posttest yang berjumlah 4 butir soal berbentuk uraian tes dengan soal, kunci jawaban, pedoman penskoran, dan posttest terlampir.

\section{Data Posttest Kemampuan Komunikasi Matematis}

Posttest dilakukan di kelas eksperimen I dan kelas Eksperimen II setelah pembelajaran. Soal yang diberikan pada posttest adalah soal kemampuan komunikasi matematis yang terdiri dari 4 soal. Soal pertama adalah soal yang mengandung aspek menulis, soal kedua juga merupakan aspek gambar, soal ketiga merupakan soal dari aspek menjelaskan dan soal keempat adalah soal yang merupakan aspek ekspresi matematika.

Rekapitulasi hasil posttest pada kelas eksperimen I berjumlah 40 orang adalah: skor untuk soal nomor 1 sampai soal nomor 4 relatif sama. Rata-rata skor nomor 1 dan nomor 2 yaitu 2,9500, sedangkan rata-rata skor nomor 3 adalah 2,8750 dan nomor 4 adalah 2,8250 .
Rekapitulasi hasil posttest pada kelas eksperimen II berjumlah 40 orang adalah: skor untuk soal nomor 1 sampai soal nomor 4 relatif berbeda. Rata-rata skor nomor 1 adalah 2,6250, rata-rata skor nomor 2 adalah 2.6000, dan rata-rata skor nomor 3 adalah 2,5250 sedangkan rata-rata skor nomor 4 adalah 2,4750 .

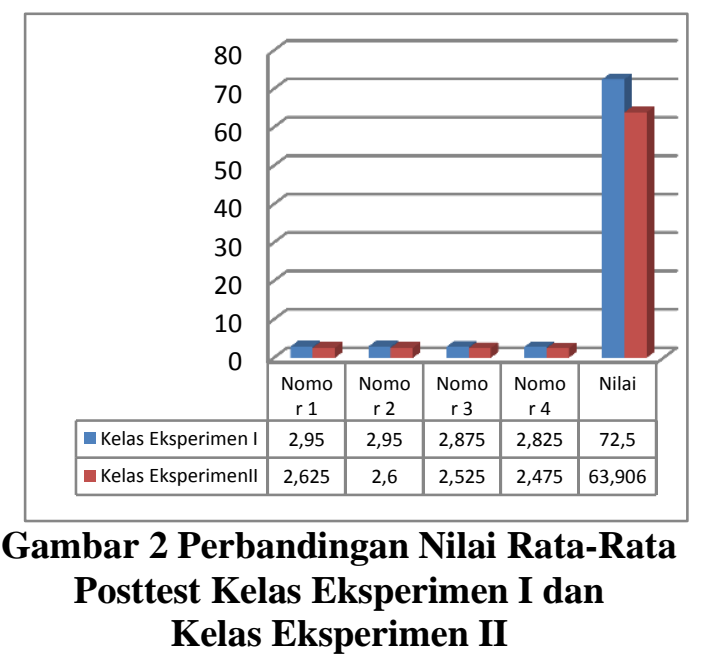

Berdasarkan gambar diatas, diperoleh bahwa nilai rata-rata skor nomor $1,2,3$, dan 4 yang lebih tinggi yaitu kelas eksperimen I dibandingkan dengan kelas eksperimen II.

\section{Analisis Data Penelitian}

\section{Analisis Statistik Deskriptif}

\section{A. Kelas Eksperimen I}

a. Aspek Menulis

$$
\begin{aligned}
& >\text { Rata-Rata } \bar{X}=2,9500 \\
& >\text { Varians } S^{2}=0,9205 \\
& >\text { Standar Deviasi } S=0,9594
\end{aligned}
$$

b. Aspek Menggambar

$>$ Rata-Rata $\bar{X}=2,9500$

$>$ Varians $S^{2}=0,9205$

$>$ Standar Deviasi $S=0,9594$

c. Aspek Menjelaskan

$>$ Rata-Rata $\bar{X}=2,8750$

$>$ Varians $S^{2}=1,0353$

$>$ Standar Deviasi $S=1,0175$

d. Aspek Ekspresi Matematika

Rata-Rata $\bar{X}=2.8250$

Rizka Aulia, Waminton Rajagukguk. Perbedaan Kemampuan Komunikasi Matematis Siswa pada Pembelajaran Kooperatif Tipe Think Pair Share dan Pembelajaran Kooperatif Tipe Two Stay Two Stray di Kelas VIII SMP N 27 Medan. Jurnal Inspiratif, Vol. 3, No. 3 Desember 2017. 
$>$ Varians $S^{2}=1,1224$

> Standar Deviasi $S=1,0595$

e. Nilai Total

$>$ Rata-Rata $\bar{X}=72,5$

$>$ Varians $S^{2}=376.202$

$>$ Standar Deviasi $S=19.3959$

B. Kelas Eksperimen I

a. Aspek Menulis

$>$ Rata-Rata $\bar{X}=2,6250$

$>$ Varians $S^{2}=1,1122$

> Standar Deviasi $S=1,0546$

b. Aspek Menggambar

> Rata-Rata $\bar{X}=2,6000$

$>$ Varians $S^{2}=1,1179$

> Standar Deviasi $S=1,0573$

c. Aspek Menjelaskan

> Rata-Rata $\bar{X}=2,5250$

$>$ Varians $S^{2}=1,4353$

> Standar Deviasi $S=1,1980$

d. Aspek Ekspresi Matematika

$>$ Rata-Rata $\bar{X}=2,4750$

$>$ Varians $S^{2}=1,4865$

$>$ StandarDeviasi $S=1,2192$

e. Nilai Total

$>$ Rata-Rata $\bar{X}=63,9060$

$>$ Varians $S^{2}=489,7600$

$>$ StandarDeviasi $S=22,1300$

\section{Analisis Statistik Inferensial}

\section{- Uji Normalitas}

Salah satu persyaratan analisis yang harus dipenuhi agar dapat menggunakan statistik parametrik uji-t adalah sebaran data harus berdistribusi normal. Untuk menguji normal tidaknya data dilakukan dengan menggunakan uji Lilliefors, dengan syarat normal jika $\mathrm{L}_{\text {hitung }}<\mathrm{L}_{\text {tabe }} l$ pada taraf $\alpha=$ 0,05 .

Berikut disajikan hasil analisis normalitas posttest penelitian pada tabel di bawah:
Tabel 2 Hasil Analisis Normalitas Posttest TPS

\begin{tabular}{|c|c|c|c|c|}
\hline \multirow[t]{2}{*}{ NO } & \multirow{2}{*}{$\begin{array}{c}\text { Aspek } \\
\text { Komunikasi } \\
\text { Matematis }\end{array}$} & \multicolumn{2}{|c|}{$\begin{array}{c}\text { Eksperimen I } \\
\text { (TPS) }\end{array}$} & \multirow[t]{2}{*}{ Keterangan } \\
\hline & & L hitung & $\mathbf{L}_{\text {tabel }}$ & \\
\hline 1 & Menulis & 0,1379 & \multirow{5}{*}{$\stackrel{?}{\stackrel{\theta}{\theta}}$} & Normal \\
\hline 2 & Menggambar & 0,1379 & & Normal \\
\hline 3 & Menjelaskan & $\mathbf{0 , 1 3 5 8}$ & & Normal \\
\hline 4 & $\begin{array}{c}\text { Ekspresi } \\
\text { Matematis } \\
\end{array}$ & 0,1358 & & Normal \\
\hline 5 & Nilai Total & 0,1020 & & Normal \\
\hline
\end{tabular}

Tabel 3 Hasil Analisis Normalitas Posttest TSTS

\begin{tabular}{|c|c|c|c|c|}
\hline \multirow[t]{2}{*}{ NO } & \multirow{2}{*}{$\begin{array}{c}\text { Aspek } \\
\text { Komunikasi } \\
\text { Matematis }\end{array}$} & \multicolumn{2}{|c|}{$\begin{array}{c}\text { Eksperimen } \\
\text { II } \\
\text { (TSTS) }\end{array}$} & \multirow[t]{2}{*}{ Keterangan } \\
\hline & & $\mathbf{L}_{\text {hitung }}$ & $\mathbf{L}_{\text {tabel }}$ & \\
\hline 1 & Menulis & $\mathbf{0 , 1 3 8 2}$ & \multirow{5}{*}{ 点 } & Normal \\
\hline 2 & Menggambar & $\mathbf{0 , 1 3 7 3}$ & & Normal \\
\hline 3 & Menjelaskan & $\mathbf{0 , 1 2 3 3}$ & & Normal \\
\hline 4 & $\begin{array}{c}\text { Ekspresi } \\
\text { Matematis }\end{array}$ & 0,1336 & & Normal \\
\hline 5 & Nilai Total & 0,1324 & & Normal \\
\hline
\end{tabular}

Dari tabel terlihat bahwa $\mathrm{L}_{\text {hitung }}<\mathrm{L}_{\text {tabe }}$ pada taraf nyata $\alpha=0,05$. Dengan demikian dapat disimpulkan bahwa distribusi skor dari setiap aspek komunikasi matematis pada kedua kelas adalah normal.

\section{- Uji Homogenitas}

Pengujian homogenitas data dilakukan dengan menggunakan uji $\mathrm{F}$ pada data posttest dengan rumus sebagai berikut

$F_{\text {hitung }}=\frac{\text { var ians terbesar }}{\text { var ians terkecil }}$

Dari perhitungan pada pengujian homogenitas data yang terlampir pada lampiran diperoleh :

\section{Tabel 4. Hasil Analisis Homogenitas} Data Penelitian

Rizka Aulia, Waminton Rajagukguk. Perbedaan Kemampuan Komunikasi Matematis Siswa pada Pembelajaran Kooperatif Tipe Think Pair Share dan Pembelajaran Kooperatif Tipe Two Stay Two Stray di Kelas VIII SMP N 27 Medan. Jurnal Inspiratif, Vol. 3, No. 3 Desember 2017. 
Pada tabel diatas terlihat bahwa setiap aspek kemampuan komunikasi matematis memiliki harga $F_{\text {hitung }}<\mathrm{F}_{\text {tabel }}$, artinya setiap sampel mempunyai varians yang sama atau tidak berbeda.

Berdasarkan tabel dapat disimpulkan bahwa telah memenuhi syarat untuk dilakukan uji beda rata-rata dengan uji-t.

\section{Uji Hipotesis}

Hipotesis yang diuji untuk Posttes adalah :

$$
\begin{array}{ll}
H_{o}: & \mu_{1}=\mu_{2} \\
H_{a}: & \mu_{1} \neq \mu_{2}
\end{array}
$$

Pengujian hipotesis ini dilakukan dengan uji-t dua arah, dengan kriteria yaitu $\mathrm{H}_{0}$ diterima jika ${ }_{1-\frac{1}{2} \alpha}<t_{\text {hitung }}<t_{1-\frac{1}{2} \alpha}$ dimana $t_{1-\frac{1}{2} \alpha}$ di dapat dari daftar distribusi t dengan $d k=\left(n_{1}+n_{2}-2\right)$ pada taraf signifikan $\alpha=$ 0,05 , untuk harga $\mathrm{t}$ lainnya $\mathrm{H}_{0}$ ditolak. (Perhitungan pada lampiran 20)

\section{Ringkasan Perhitungan Uji Hipotesis}

Berdasarkan tabel diatas, dari data posttest diperoleh bahwa $t_{\text {hitung }}$ tidak berada dalam interval $-\mathrm{t}_{\text {tabel }}<\mathrm{t}_{\text {hitung }}<\mathrm{t}_{\text {tabel }}$, pada taraf $\alpha=$ 0,05 dan $\mathrm{dk}=40+40-2=78$. Yang berarti bahwa $\mathrm{H}_{0}$ ditolak dan $\mathrm{H}_{\mathrm{a}}$ diterima, sehingga dapat disimpulkan bahwa komunikasi matematis siswa yang diajarkan dengan model pembelajaran think pair share (TPS) berdeda dengan komunikasi matematis siswa yang diajarkan dengan model pembelajaran two stay two stray (TSTS) pada pokok pembahasan bangun ruang kubus dan balok di kelas VIII SMP Negeri 27 Medan tahun ajaran 2016/2017.

\section{Pembahasan Hasil Penelitian}

Penelitian ini mengungkap perbedaan kemampuan komunikasi matematis siswa yang belajar dengan menggunakan model pembelajaran kooperatif tipe Think Pair Share (TPS) dan Two Stay Two Stray

\begin{tabular}{|c|c|c|c|c|}
\hline \multirow[b]{2}{*}{ NO } & \multirow{2}{*}{$\begin{array}{c}\text { Aspek } \\
\text { Komunikasi } \\
\text { Matematis }\end{array}$} & \multicolumn{2}{|c|}{ Posttest } & \multirow[b]{2}{*}{ Ket } \\
\hline & & $\mathbf{F}_{\text {hitung }}$ & $\mathbf{F}_{\text {tabel }}$ & \\
\hline 1 & Menulis & 0.8276 & \multirow{5}{*}{ 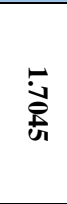 } & Homogen \\
\hline 2 & Menggambar & 0.8234 & & Homogen \\
\hline 3 & Menjelaskan & 0.7213 & & Homogen \\
\hline 4 & $\begin{array}{c}\text { Ekspresi } \\
\text { Matematis }\end{array}$ & 0.7551 & & Homogen \\
\hline 5 & Nilai Total & 0.7681 & & Homogen \\
\hline
\end{tabular}
(TSTS). Pada penelitian ini digunakan dua kelas sebagai sampel penelitian yaitu sebagai kelas eksperimen I (Belajar dengan model TPS) dan sebagai kelas eksperimen II (Belajar dengan model TSTS).

Dari hasil penelitian menunjukkan bahwa kemampuan komunikasi matematis siswa yang belajar dengan menggunakan model pembelajaran kooperatif tipe TPS berbeda dengan kemampuan komunikasi matematis siswa yang belajar dengan menggunakan model pembelajaran kooperatif tipe TSTS, hal ini dapat dilihat dari perolehan uji hipotesis yaitu $t_{\text {hitung }}=$ 1,7489 dan $\mathrm{t}_{\text {tabel }}=1,667$

Berdasarkan hasil analisis data posttes, rata-rata skor kemampuan komunikasi matematis kelas yang diajarkan dengan model pembelajaran TPS relatif sama, yaitu untuk nomor 1 dan nomor 2 yaitu 2,9500, sedangkan rata-rata skor nomor 3 adalah 2,8750 dan nomor 4 adalah 2,8250.

Berdasarkan hasil analisis data posttes, rata-rata skor kemampuan komunikasi matematis kelas yang diajarkan dengan model pembelajaran TSTS relatif berbeda, yaitu untuk nomor 1 adalah 2,6250, ratarata skor nomor 2 adalah 2.6000 , dan ratarata skor nomor 3 adalah 2,5250 sedangkan rata-rata skor nomor 4 adalah 2,4750 .

- Dari hasil analisis data posttest kedua kelas nilai rata-rata skor kemampuan komunikasi matematis kelas eksperimen I lebih tinggi dari pada kelas eksperimen II. Meskipun demikian, baik TPS maupun TSTS ternyata sama-sama dapat meningkatkan kemampuan komunikasi matematis siswa di kedua kelas tersebut pada materi Kubus dan Balok.

\section{Kesimpulan}

Berdasarkan hasil penelitian maka dapat disimpulkan bahwa: Komunikasi matematis siswa yang diajarkan dengan model pembelajaran Think Pair Share (TPS)

Rizka Aulia, Waminton Rajagukguk. Perbedaan Kemampuan Komunikasi Matematis Siswa pada Pembelajaran Kooperatif Tipe Think Pair Share dan Pembelajaran Kooperatif Tipe Two Stay Two Stray di Kelas VIII SMP N 27 Medan. Jurnal Inspiratif, Vol. 3, No. 3 Desember 2017. 
berdeda dengan komunikasi matematis siswa yang diajarkan dengan model pembelajaran Two Stay Two Stray (TSTS) pada pokok pembahasan bangun ruang kubus dan balok di kelas VIII SMP Negeri 27 Medan tahun ajaran 2016/2017. Hal ini dapat dilihat dari perolehan uji hipotesis dimana nilai $t_{\text {hitung }}$ tidak berada pada interval $-\mathrm{t}_{\text {tabel }}<\mathrm{t}_{\text {hitung }}<\mathrm{t}_{\text {tabel }}$ yaitu $\mathrm{t}_{\text {hitung }}=1,7489$ dan $\mathrm{t}_{\text {tabel }}=1,667$.

\section{REFERENCES}

Abdurrahman, M. (2012). Anak Berkesulitan Belajar. Penerbit Rineka Cipta. Jakarta.

Byod, W, dkk. 2014. Feeling Good about Teaching Mathematics: Addressing Anxiety amongst Pre-Service Teachers. Scientific Research, Vol.5, P.207,208.

Darkasyi, Muhammad. (2014). Peningkatan Kemampuan Komunikasi Matematis dan Motivasi Siswadengan Pembelajaran Pendekatan Quantum Learning pada Siswa SMP Negeri 5 Lhokseumawe.Vol. 1. No. 1

Husna,dkk, (2013). Peningkatan Kemampuan Pemecahan Masalah Dan Komunikasi Matematis Siswa Sekolah Menengah Pertama Melalui Model Pembelajaran Kooperatif Tipe Think-Pair-Share (TPS).Jurnal Peluang.Vol. 1. No. 2.

Isjoni, H. (2011).Cooperatif Learning. Alfabeta. Bandung.

Kusumaningrum, Ratih, dkk. (2015). Eksperimentasi Model Pembelajaran Kooperatif Tipe Two Stay Two Stray (TSTS), Numbered Heads Together (NHT), Dan Think Pair Share (TPS) Pada Materi Lingkaran Ditinjau Dari Kreativitas Belajar Matematika Siswa SMP Negeri Dikabupaten Sukoharjo. Vol.3, No.7, ISSN.2339-1685.

Mahmudi, A. (2009). Komunikasi dalam Pembelajaran Matematika. Jurnal MIPMIPA UNHALU 8:1-9
Mayasari, Dian., (2015), Penerapan Model Pembelajaran Two Stay Two Stray untuk Meningkatkan Komunikasi Matematis dan Motivasi Siswa, Prosiding Seminar Nasional Matematika dan Pendidikan Matematika UMS 2015, ISBN : 978.602.361.002.0

Sa'ad, T.U, Adamu, A, dan Sadiq, A.M. (2014). The Causes of Poor Performance in Mathematics among Public Senior Secondary School Students in Azare Metropolis of Bauchi State. Nigeria. Journal of Research \& Method in Education. Vol.4. No.6. e-ISSN.2320-7388. P. 32.

Santillán, A.G, Escalera-Chávez,M.E dan Moreno-García, E, SantanaVillegas,.d.C. (2015). Factors that Explains Student Anxiety toward Mathematics. Eurasia Journal of Mathematics, Science \& Technology Education. Vol.12. No.2. 361. ISSN.1305-8223. P.361.

Sudjana. (2005). Metoda Statistika. Penerbit Tarsito. Bandung.

Surya, E. (2012). "Upaya Pembelajaran Matematika Berbasis Masalah dengan Strategi Konflik Kognitif". Jurnal Tematik, PPS Dikdas Unimed. 7, (1), 1-14, ISSN : 19790633.

Surya, E., Sabandar, J., Kusumah, Y.S., and Darhim. (2013). Improving of Junior High School Visual Thinking Representation Ability in Mathematical Problem Solving by CTL. IndoMS. J.M.E, Vol. 4 No. 1, pp. 113-126.

Ulfah, Fitriah. (2010). Pengaruh Model Pembelajaran Kooperatif Teknik Two Stay Two Stray Terhadap Kemampuan Komunikasi Matematik Siswa. Universitas Islam Negeri Syarif Hidayatullah Jakarta

Rizka Aulia, Waminton Rajagukguk. Perbedaan Kemampuan Komunikasi Matematis Siswa pada Pembelajaran Kooperatif Tipe Think Pair Share dan Pembelajaran Kooperatif Tipe Two Stay Two Stray di Kelas VIII SMP N 27 Medan. Jurnal Inspiratif, Vol. 3, No. 3 Desember 2017. 